\title{
Development of the Packer and its Application for Fixing Production Casing Leaks of Oil and Gas Wells
}

\author{
Roman A. Vaganov, Fedor A. Buryukin, Svetlana S. Kositcyna, Maksim V. Zhukov
}

\begin{abstract}
A large number of oil and gas wells at the late stage of operation are characterized by high and constantly increasing water cut of the extracted product. One of the reasons for the high water cut is the presence of production casing leaks. The occurrence of production casing leaks is connected both with the quality of primary cementing and various operating conditions of wells. To solve this problem, different technologies are applied with the use of plug-back mixtures and technical means, each of which has its own advantages and disadvantages as well as its own application area. In particular, the packers of various structures are widely used. Among the many options, the retrievable packers benefit in the market even in the case of their relatively high costs due to their easy removal and reuse. The article presents the results of the work on the development of a new structure of the retrievable packer with cable termination glands and hydraulic opening system in the well. The structure of the retrievable packer was tested in the laboratory conditions with the use of a purpose-designed test rig and in the field environment. The designed stand for testing individual structural units and the packer as a whole is a casing string simulator in which the test packer is placed. The stand is equipped with a hydraulic cylinder to simulate the movement of the packer, hydrostations to simulate hydraulic loads on the packer and breakthrough fluid from the leakage of the production string, circulation pumps to simulate circulation pumping through the packer. Field tests were carried out at one of the fields in Eastern Siberia, Russian Federation, at wells with very high water cuts. Full compliance with the claimed requirements concerning the reliability of operation of mechanisms and well plugging of the leak interval was shown. Besides that, the advantage of the packer is the possibility of communication between spaces above and below the packer. At the same time, the possibility of technological washing, acid treatment, killing and other technological operations is preserved. The use of packer during repair and insulation works in wells has made it possible to reduce the duration of works on the average by 2.5 times.
\end{abstract}

Keywords : Retrievable packer, mechanical water shut-off, test rig, field tests, experimental study.

Revised Manuscript Received on December 30, 2019.

* Correspondence Author

Roman A. Vaganov*, Siberian Federal University, 82, Svobodny Ave., bdg 6, Krasnoyarsk, 660041, Russia.

Fedor A. Buryukin, Siberian Federal University, 82, Svobodny Ave., bdg 6, Krasnoyarsk, 660041, Russia

Svetlana S. Kositcyna, Siberian Federal University, 82, Svobodny Ave., bdg 6, Krasnoyarsk, 660041, Russia

Maksim V. Zhukov, LLC “SSK Group”, 20d, Zheleznodorozhnikov St., Krasnoyarsk, 660090, Russia, 660099

(C) The Authors. Published by Blue Eyes Intelligence Engineering and Sciences Publication (BEIESP). This is an open access article under the CC BY-NC-ND license (http://creativecommons.org/licenses/by-nc-nd/4.0/)

\section{INTRODUCTION}

The issue of developing new technical means, which can be effectively used to solve problems related to leaks in production casing, comes at an opportune time, in particular, to take account of the well stock growth at a late stage of development. Although well plugging is still the main method for fixing production casing leaks, there are numerous reports of its inefficiency and the need to repeat the procedure several times. Widely used technology of fixing leaks with the help of lowering into the well an additional production casing and subsequent cementing is not free from shortcomings, the main of which are the high cost of repair and insulation works (RIW) and restriction of the full bore of well. For water shut-off in wells, which have single local violations of the length usually, more than $20 \mathrm{~m}$, more often technical means are applied, such as profile packers, metal patches and packers or double-packer assemblies of various structures, as demonstrated in [1], [2].

It has been revealed that isolation works for water shut-off in wells at some fields in Russia are up to $25 \%$, and the technological efficiency of RIW in terms of oil flow rate growth has not exceeded 1.3 tons per day, as reported in [3], [4].

Table I: The most common technologies for fixing

leaks in production casing of wells according to [1]

\begin{tabular}{|c|c|c|c|c|}
\hline $\begin{array}{l}\text { Technica } \\
\text { l means }\end{array}$ & $\begin{array}{l}\text { Technolo } \\
\text { gy } \\
\text { features }\end{array}$ & Advantages & $\begin{array}{l}\text { Disadvantage } \\
\mathrm{s}\end{array}$ & $\begin{array}{l}\text { Application } \\
\text { area }\end{array}$ \\
\hline $\begin{array}{l}\text { Metal } \\
\text { patch }\end{array}$ & $\begin{array}{l}\text { Rolling } \\
\text { round } \\
\text { cross-sect } \\
\text { ion tube } \\
\text { over the } \\
\text { inner } \\
\text { wall of } \\
\text { the PC* }\end{array}$ & $\begin{array}{l}\text { Insignifican } \\
t \text { restriction } \\
\text { of the PS, } \\
\text { length of } \\
\text { insulated } \\
\text { area up to } \\
300 \text { m, } \\
\text { installation } \\
\text { depth up to } \\
3000 \mathrm{~m} \text { (for } \\
\text { two-layer } \\
\text { patches) }\end{array}$ & $\begin{array}{l}\text { 1) for } \\
\text { installation } \\
\text { depths of } \\
\text { more than } \\
1500 \mathrm{~m} \text {, fixed } \\
\text { patches are } \\
\text { used. } \\
\text { 2) permissible } \\
\text { draw-down } \\
\text { pressure up to } \\
20 \text { MPa. } \\
\text { 3) casing } \\
\text { restriction in } \\
\text { the isolation } \\
\text { interval. }\end{array}$ & $\begin{array}{l}\text { Multiple } \\
\text { abnormalities } \\
\text { at depths up to } \\
3000 \mathrm{~m} \text { above } \\
\text { the ESP* } \\
\text { installation }\end{array}$ \\
\hline
\end{tabular}




\begin{tabular}{|c|c|c|c|c|}
\hline $\begin{array}{l}\text { Technica } \\
\text { l means }\end{array}$ & $\begin{array}{l}\text { Technolo } \\
\text { gy } \\
\text { features } \\
\end{array}$ & Advantages & $\begin{array}{l}\text { Disadvantage } \\
\mathrm{s}\end{array}$ & $\begin{array}{l}\text { Application } \\
\text { area }\end{array}$ \\
\hline $\begin{array}{l}\text { Double- } \\
\text { packer } \\
\text { assembly }\end{array}$ & $\begin{array}{l}\text { Lowering } \\
\text { of the } \\
\text { double-p } \\
\text { acker } \\
\text { assembly } \\
\text {, PS* } \\
\text { between } \\
\text { packers } \\
60-114 \\
\text { mm }\end{array}$ & $\begin{array}{l}\text { Installation } \\
\text { at depths up } \\
\text { to } \\
2500-2800 \\
\text { m. } \\
\text { Possibility } \\
\text { of washing } \\
\text { below the } \\
\text { depth of the } \\
\text { assembly } \\
\text { installation }\end{array}$ & $\begin{array}{l}\text { 1) casing } \\
\text { restriction up } \\
\text { to } 34-95 \mathrm{~mm}\end{array}$ & $\begin{array}{l}\text { Multiple } \\
\text { abnormalities } \\
\text { at depths up to } \\
1000 \text { m below } \\
\text { the ESP } \\
\text { installation }\end{array}$ \\
\hline $\begin{array}{l}\text { Addition } \\
\text { al liner } \\
\text { tie-back }\end{array}$ & $\begin{array}{l}\text { Round } \\
\text { cross-sect } \\
\text { ion tube } \\
\text { lowering } \\
\text { and } \\
\text { cementin } \\
\text { g }\end{array}$ & $\begin{array}{l}\text { Permissible } \\
\text { draw-down } \\
\text { pressure up } \\
\text { to } 20 \mathrm{MPa} \text {, } \\
\text { low cost }\end{array}$ & $\begin{array}{l}\text { 1) restriction } \\
\text { of the casing } \\
\text { up to } 100 \mathrm{~mm} \\
\text { 2) the } \\
\text { impossibility } \\
\text { of the } \\
\text { subsequent } \\
\text { retrieval }\end{array}$ & $\begin{array}{l}\text { Multiple } \\
\text { abnormalities } \\
\text { at depths up to } \\
500 \mathrm{~m} \text { below } \\
\text { the ESP } \\
\text { installation }\end{array}$ \\
\hline $\begin{array}{l}\text { Downhol } \\
\text { e } \\
\text { pumping } \\
\text { equipme } \\
\text { nt + } \\
\text { packer }\end{array}$ & $\begin{array}{l}\text { The leak } \\
\text { interval is } \\
\text { separated } \\
\text { by a } \\
\text { packer }\end{array}$ & $\begin{array}{l}\text { Low labor } \\
\text { input, } \\
\text { relatively } \\
\text { simple } \\
\text { design }\end{array}$ & $\begin{array}{l}\text { 1) the } \\
\text { necessity of } \\
\text { the packer } \\
\text { sealing } \\
\text { 2) low } \\
\text { duration of } \\
\text { effect } \\
\begin{array}{l}\text { 3) Efficient } \\
\text { use in wells } \\
\text { with oil-gas } \\
\text { ratio not } \\
\text { exceeding } \\
100 \mathrm{~m}^{3} / \mathrm{m}^{3}\end{array}\end{array}$ & $\begin{array}{l}\text { Multiple } \\
\text { abnormalities } \\
\text { along the } \\
\text { entire length } \\
\text { of the PC }\end{array}$ \\
\hline $\begin{array}{l}\text { Profile } \\
\text { packer }\end{array}$ & $\begin{array}{l}\text { Rolling } \\
\text { of a } \\
\text { corrugate } \\
d \text { tube } \\
\text { over the } \\
\text { inner } \\
\text { wall } \\
\end{array}$ & $\begin{array}{ll}\text { Ability to } \\
\text { install in } \\
\text { uncased } & \\
\text { well sites } & \end{array}$ & $\begin{array}{l}\text { 1) raise } \\
\text { requirements } \\
\text { for PC } \\
\text { preparation } \\
\text { 2) long } \\
\text { installation } \\
\text { process } \\
\end{array}$ & $\begin{array}{l}\text { Abnormalities } \\
\text { of the PC at } \\
\text { depths up to } \\
3000 \mathrm{~m} \text { above } \\
\text { the ESP* } \\
\text { installation }\end{array}$ \\
\hline
\end{tabular}

* PC - production casing; ESP - electrical submersible pump; PS - producing string

Besides fixing leaks, packers are used to test various horizons for oil, gas or water inflows according to [5], [6], during acid treatments of bottom-hole formation zone and formation hydraulic fracturing operations, during cementing, well completion, etc., as demonstrated in [7]-[10].

Packers can be classified as conventional and swelling. Conventional packers are installed mechanically or hydraulically, as demonstrated in [11]. Conventional packers can be divided into two groups: permanent and retrievable.

Permanent packers can only be removed from the wellbore by drilling. The retrievable packer may or may not be go-devil, but removal from the wellbore normally does not require milling. Removal is usually accomplished by some form of pipe manipulation, such as rotating or tensioning of the producing string. Fixed packers are simpler in design and can usually be used at higher temperatures and pressures than retrievable packers. Besides, they have a more compact structure and can, therefore, be used in widely deviated wells.

Retrievable packers are less frequently used in wells at high pressure and temperature and are usually more expensive due to the complexity of their structure. But the possibility of removing the packer from the wellbore and reusing it is an important advantage as is proven in [11], [12].

Swelling packers go off, reacting with different types of liquids, such as water or oil. Accordingly, they can be used to limit the inflow of water and oil [20], [21]. Due to the absence of moving parts, these packers provide a simple, one-time solution for efficient isolation, saving time and installation costs. Swelling packers are made of complex polymers that are suitable for high-pressure applications such as multistage formation fracturing, as well as for sealing in flow wells, for example, when inflow control devices are used.

The disadvantages of packers include integrity damages of the rubber or polymer part of the packer due to the impact of high formation temperatures and pressure, as demonstrated in [13], [14], acid compositions for bottom-hole formation zone treatment and formation hydraulic fracturing, as is proven in [15], [16]; the possibility of cross cracks in wells, especially in inclined and horizontal ones as shown in [17], [18]; complexity of packer seating operations in horizontal wells and widely inclined wells, as demonstrated in [19]. Besides, effective isolation with the use of packer is often impossible in case of long intervals of the well leak.

The disadvantages of most of them include a short duration of leak-proofness period, increased requirements for well preparation and, in some cases, increased emergency danger, for example, when installing a shut-off packer as part of the pumping equipment, which is installed below the leaks of the production casing and during operation, is sprinkled with rock cuttings from the damaged interval.

For solving the problems connected with the disadvantages of some or other packer structures, new technical decisions are developed.

A patent review of developments in the field of packer designs and packer systems showed that the leading countries in the number of publications of title documents in this area are the Russian Federation, the USA, China, and Canada.

Among patent holders in the Russian Federation, Tatneft LLC has the largest patent portfolio for the subject of technology, in the world - Baker Hughes Inc. (USA), PetroChina Co LTD (China), Halliburton Energy Serv. Inc. (USA). Schlumberger.

Scientific research related to repair and insulation work using packer equipment is mainly aimed at:

1. improving the reliability of sealing by supplying packer equipment with an electronic measuring device for monitoring the state of tightness;

2. improving the reliability of sealing by checking the complete sealing in the place of the cable entry;

3. improving the quality of sealing through the use of sealing elements made of materials with special properties, namely: magnetorheological elastomeric material; shape memory polymers; material with carbon composite particles; a composite material swelling depending on the amount and physico-chemical properties of the well fluid. The article presents the results of works on the development of a new structure of a retrievable packer with cable termination glands and hydraulic opening system in the well.

\section{PACKER STRUCTURE}

The packer structure is shown in Figure 1.

The development objective was to increase the reliability of sealing the leak interval of the operating casing below the lowering production equipment without emergency situations and the preservation of the communication between the spaces above and below the packer. 
The packer contains top and bottom sealing units, an elastic plugging hose equipped with an inflation valve unit is installed between two adjacent sealing units with insulation joints. The plugging hose is made of metalized wire, cord fabric and rubber layers.

Once the packer is installed, it is still possible for the fluid to pass through the tube side, and thus the communication between the spaces above and below the packer is created.

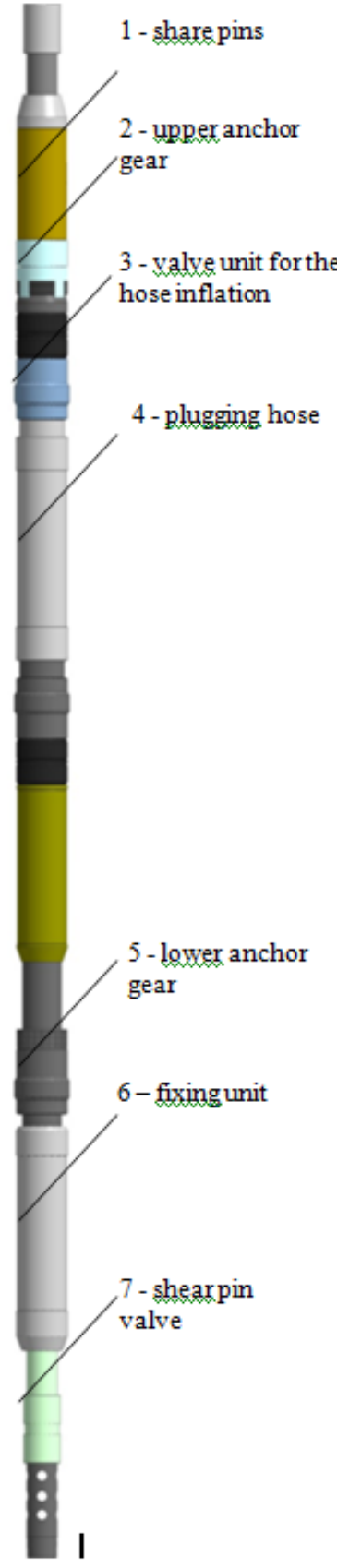

Fig. 1.The packer structure

Operational and technical parameters of the packer are presented in Table 2:

Table II. Operational and technical parameters of the packer

\begin{tabular}{|l|l|}
\hline Parameter & Value \\
\hline $\begin{array}{l}\text { Passage diameter of the production } \\
\text { casing }\end{array}$ & $178 \mathrm{~mm}$ \\
\hline Wall thickness of the production casing & $8.7-10.4 \mathrm{~mm}$ \\
\hline $\begin{array}{l}\text { Maximum inside diameter of the } \\
\text { production casing at the plugging point }\end{array}$ & max. $160.0 \mathrm{~mm}$ \\
\hline
\end{tabular}

\begin{tabular}{|c|c|}
\hline Parameter & Value \\
\hline Borehole inclination & max. 80 degrees \\
\hline $\begin{array}{l}\text { Maximum pressure drop between areas } \\
\text { separated by the packer }\end{array}$ & $25 \mathrm{MPa}$ \\
\hline Packer hose filling pressure & $5^{+1} \mathrm{MPa}$ \\
\hline External diameter & $150 \mathrm{~mm}$ \\
\hline $\begin{array}{l}\text { External diameter measured by the } \\
\text { anchor skids }\end{array}$ & $166 \mathrm{~mm}$ \\
\hline Length, max. & $9500 \mathrm{~mm}$ \\
\hline Diameter of the packer bore, min. & $62 \mathrm{~mm}$ \\
\hline $\begin{array}{l}\text { Activation force of the packer lower } \\
\text { packing unit }\end{array}$ & $40 \mathrm{kN}$ \\
\hline $\begin{array}{l}\text { Activation force of the packer upper } \\
\text { packing unit }\end{array}$ & $80 \mathrm{kN}$ \\
\hline $\begin{array}{l}\text { Breakout force when lifting the plugging } \\
\text { system }\end{array}$ & $\max .98 \mathrm{kN}$ \\
\hline $\begin{array}{l}\text { Maximum tensile axial stress on the } \\
\text { packer body }\end{array}$ & $490 \mathrm{kN}$ \\
\hline Maximum operating temperature & $100^{\circ} \mathrm{C}$ \\
\hline Mass & $260 \mathrm{~kg}$ \\
\hline Installation method & hydromechanical \\
\hline Removal method & $\begin{array}{l}\text { mechanical, without rotation, } \\
\text { by moving the producing string } \\
\text { upwards }\end{array}$ \\
\hline
\end{tabular}

\section{APPLICATION TECHNIQUE}

\section{A.Packer seating}

The system is installed in the well autonomously in the leak interval, which is below the lowered production equipment. After the exact leak interval is found and the well is prepared, the autonomous system is run in the planned interval on the drilling tool. Further, after reaching the planned interval and geophysical positioning in the interval of disturbance, the lower anchor gear (5) is activated by a mechanical movement and the suspension is unloaded up to 4 tons below its own weight. At the same time the lower packing unit is activated, the insulation joints of which seal the annular space below the interval of leaks. The next stage is the creation of a design surplus pressure in the pipe side, which depends on the criteria of a particular well, after which the plugging hose (4) is blown up, and it plugs the flow area in the well in the interval of leaks. The fluid is fed into the hose from the pipe side through the valve unit for the hose inflation (3). Then, by mechanical unloading up to $\mathrm{N}$ tons (regulated by pins depending on the well conditions) below own weight, share pins (1) are cut off, the connecting channel between the pipe side and the hose (4) interior is closed, and then the upper packing unit (2) is sealed with the design axial stress. After these measures have been taken, the packer system is pressurized against the annular space for the test pressure of the production casing, and the packer is confirmed to be in working position. Then, by creating the design surplus pressure in the tube side the valve (7) is cut off, and the drilling tool is disconnected from the packer system by a specific releasable joint (supplied separately).

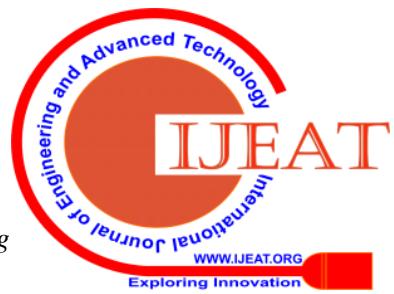


After performing the work, the communication between spaces above and below the packer remains free due to the free passage through the pipe side, while the interval of leaks remains reliably isolated.

\section{B. Packer removal}

Smooth upward movement of the producing string creates a force not exceeding a value of $98 \mathrm{kN}$, with the series release of the upper packing unit, the opening of the valve unit and reduction of pressure inside the hose, the release of the lower packing unit and separation of the anchor.

\section{TEST PROCEDURES}

\section{A. Laboratory testing}

For testing various technical solutions and materials for the packer packing elements, a test rig was designed and manufactured. The peculiarity of the rig is the possibility of testing separate units and the packing assembly, as well as the possibility of fluid leakage imitation from the production casing through the packer elements. The working fluids are water, oil or hydraulic oil. The scheme of the rig is shown in Fig. 2.

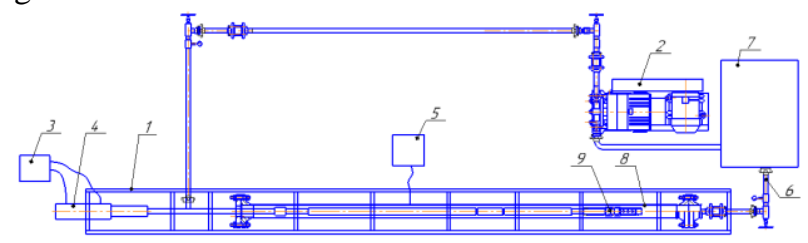

Fig.2. Basic diagram of the test rig. 1 - Rig frame, 2 Pump, 3 - Hydropower station, 4 - Hydraulic cylinder, 5

- Hydropower station for imitation of the fluid channeling, 6 - Pipeline, 7 - Volume capacity, 8 - Casing simulator, 9 - Packer.

The rig tests of the packer were carried out as follows: the packer was placed inside the casing simulator and mounted on the rig frame. The simulator is a piece of the casing with $\mathrm{DN}=178 \mathrm{~mm}$. The simulator and packer are placed on the rig frame and auxiliary piping, gauges and pumps are connected; the simulator is connected to the hydraulic cylinder.

The self-contained packer is tested in two steps:

1. Packer seating in the casing employing a hydraulic cylinder,

2. Simulation of hydraulic loads on the packer.

The packer seating in the casing simulator is performed as follows.

The packer is initially set to the extreme left position. The hydraulic cylinder moves the packer to the right, and during the movement, the force on the packer starts to grow after the ram catch hooking against the casing column. Having created an effort on the lower sealing unit of the packer, the fluid is pumped into the packer interior, and the surplus pressure is created. If this occurs, the packer is loaded, and the valve inside the packer closes the interior of the inflatable element. After reaching the required value of pressure inside, the upper rams are put into gear with the casing column. Further, an additional force was created on the packer for its final seating and cutting off the back pressure valve of the packer. The packer is disconnected from the hydraulic cylinder, and the auxiliary piping is installed. The pump determines the leak-proofness and quality of the self-contained packer seating. After that, the circulation pumping is carried out through the casing column simulator. Control of operation in different modes is carried out according to the gauge readings.After dismantling the packer from the rig, visual and instrumental monitoring of dimensions of packer elements was carried out to detect defects. The laboratory testing results demonstrated that all its performance indicators meet the expected requirements, and the design is suitable for pilot testing at the oil and gas field.

\section{B. Field testing}

Then packing assemblies were transported to the wells of one of the East Siberian fields with very high water cut.

Well 1: the inclination angle of the well in the interval of installation was $67^{\circ}$; the interval of leaks was at a depth of 1695-1705 m; the associated water cut in the extracted product was up to $99 \%$. Well 2: the inclination angle of the well in the interval of the unit was $74^{\circ}$; the interval of leakage was at a depth of 2280-2310 m; the associated water cut in the extracted product was up to $99 \%$. This well was used to fix the leaks and put the well into operation. The system was installed as an intermediate link in the packaging arrangement of the submersible equipment when lowering the cable downhole device, in particular, the electric centrifugal pump. After the exact location of the production casing the leak interval was found, the pumping equipment was lowered into the design interval to a depth below the leak interval of the production casing. The packer was assembled in such a way that the upper sealing unit was placed above the leak interval, the lower sealing unit - below the leak interval, and the plugging hose - at the leak interval level. With the help of lifting facilities (mobile crane, truck-mounted workover rig), the assembled system was laid on the catwalk mounted at the wellhead. The cable of the electric centrifugal pump, previously cut off from the main drum, was dragged into the cable channel. By doing so, the length of the section was left taking into account that after lifting and installation of the packer system, the cable splicing with the main cable line on the drum would be performed. Then the packer system was lifted to the required height above the wellhead with the help of the truck-mounted workover rig, after which it was connected to the production tubing located in the wellhead retaining device (spider). The connection was made with the help of a mount hoisting swivel to avoid the rotation of a section of the packer system located above the mount hoisting swivel. Then the cable was fixed on the packaging arrangement with the help of fixing belts, the cut-off section of the cable was spliced with the main cable line and went on running into the well on the production tubing. After reaching the planned depth, geo-physical positioning of the submersible equipment to the leak interval was performed. Further, after the installation of the base plate and hydraulic pressure testing of the cable termination glands of the Christmas-tree of the well, the anchor was activated by mechanical movement and the suspension was unloaded up to 4 tons below its own weight, and the lower packing unit was activated, the insulation joints of which seal the annular space below the interval of leaks. 
Further, the surplus pressure of 50 atm was created in the pipe side for blowing up the hose and well plugging of the flow area in the leak interval. Then the pins in the upper packing unit were cut off by mechanical unloading up to 8 tons below own weight. In the result, the connecting channel between the pipe side and the hose interior was closed, and then the upper packing unit was sealed with actual unloading until the base plate was completely seated on the Christmas-tree cross-member. After the completion of the work, the communication between the spaces above and below the packer remained free due to the unsealed ring space of the cable channel, which makes it possible to carry out technological washing and killing operations in well operation.

The duration of the production maintenance of well with the use of packer did not exceed 200 hours, while the average duration of similar works with the use of double packer arrangements was about 500 hours.

After the well 1 was put into operation, its performance parameters were: $\mathrm{Q}_{\mathrm{f}}=110 \mathrm{~m}^{3}$, water cut $87 \%$; for the well 2 these were: $\mathrm{Q}_{\mathrm{f}}=124 \mathrm{~m}^{3}$, water cut $72 \%$. These parameters correspond to the estimated potential for each well.

\section{CONCLUSION}

As a result of experimental research, a new structure of the retrievable packer was proposed and tested in the field environment.

The packer can be used for a variety of vertical and directional production casings of oil and gas wells while providing reliable sealing at any interval but not only above the pump equipment run into the well. It will allow for the elimination of limitation of the well operating potential and emergency situations when performing repair operations.

The cable passage channel in the packer structure has the function of providing communication between the spaces above and below the packer, which solves the issues of gas withdrawal during operation, technological flushing and killing.

Field tests of the packer on deviated wells showed the effectiveness of the developed design for completely covering the leakage interval in the wells. Due to the duration of the current well repair using a packer did not exceed 200 hours.

The main competitive products are packer systems with hermetic cable termination glands and two-packer configurations (production of Weserford, Schlumberger, and Halliburton) but the given products are not structurally identical to the developed packer.

In this regard, the duration of repair and insulation works with the use of the developed packer is on the average 2.5 times less, and the planned cost upon sale is three times less. Due to the reduction of the duration of repair and insulation works at the installation site, a significant increase in oil flow rate is expected, and a decrease in operating costs is expected to be more than the US $\$ 23.5$ thousand.

\section{ACKNOWLEDGMENT}

The work was completed with financial support from the Ministry of Education and Science of the Russian Federation within the framework of the Federal Target Program
«Research and development in priority areas of the scientific and technological complex of Russia for 2014-2020», action 1.3. Unique identifier of applied research (project): RFMEFI57817X0236.

\section{REFERENCES}

1. F. Ahmed, S. Aliev and E. Iskenderov, "State and problems of production string leaks fixing in wells of BUZOVNA-MASHTAGA field," Exploration and development of oil and gas fields, vol. 3, no. 56, pp. 141-144, 2015.

2. S. Xindi and B. Baojun, "Comprehensive review of water shutoff methods for horizontal wells," Petroleum Exploration and Development, vol. 44, no. 6, pp. 1022-1029, 2017.

3. R. Hasanov, "Packers and technology of formation separation," Drilling and oil, vol. 12, p. 24, 2005

4. Tikunkov, I. Mukhutdirov and Y. Soloviev, "Experience in liquidation of production string leaks in PAO Orenburgneft," Engineering practice, vol. 8, pp. 40-44, 2016.

5. P. Quinn, J. Cherry and B. Parker, "Combined use of straddle packer testing and FLUTe profiling for hydraulic testing in fractured rock boreholes," Journal of Hydrology, vol. 524, pp. 439-454, 2015.

6. Y. Yihdego, "Hydraulic In situ Testing for Mining and Engineering Design: Packer Test Procedure, Preparation, Analysis and Interpretation," GeotechGeolEng, vol. 35, pp. 29-44, 2017.

7. Aadnøy and R. Looyeh, Petroleum Rock Mechanics (Second Edition)Drilling Operations and Well Design, Amsterdam: Elsevier, 2019.

8. K. Nabhani and F. Khan, Nuclear Radioactive Materials in the Oil and Gas Industry, Amsterdam: Elsevier, 2020.

9. Z. Tong, Q. Ye, J. Qiana, Z. Hao and L. Wang, "Down-hole isolation towards high-temperature reservoir using packing elements with swellable thermo-plastic vulcanizates," Journal of Petroleum Science and Engineering, vol. 172, pp. 964-975, 2019.

10.M. Bai, A. Shen, L. Meng, J. Zhu and K. Seng, "Well completion issues for underground gas storage in oil and gas reservoirs in China," Journal of Petroleum Science and Engineering , vol. 171, pp. 584-591, 2018.

11.Guo, X. Liu and X. Tan, Petroleum Production Engineering (Second Edition), Amsterdam: Elsevier, 2017.

12.J. DeGeare, The Guide to Oilwell Fishing Operations (Second Edition), Waltham: Gulf Professional Publishing, 2015.

13.L. Dong, K. Li, X. Zhu, Z. Li, D. Zhang, Y. Pan and X. Chen, "Study on high temperature sealing behavior of packer rubber tube based on thermal aging experiments," Engineering Failure Analysis, 2019.

14.H. Patel, S. Salehi, R. Ahmed and C. Teodoriu, "Review of elastomer seal assemblies in oil \& gas wells: Performance evaluation, failure mechanisms, and gaps in industry standards," Journal of Petroleum Science and Engineering, vol. 179, pp. 1046-1062, 2019.

15.Z. Liu, S. Li, L. Zhang, F. Wang, P. Wang, L. Han, Y. Ma and H. Zhang, "Analysis of Sealing Mechanical Properties of Fracturing Packer Under Complex Conditions," Journal of Failure Analysis and Prevention, pp. 1-14, 2019.

16.Zhu, Y. Lin, H. Zhang, Y. Li, D. Zeng, W. Liu, C. Qiang and K. Deng, "Corrosion evaluation of packer rubber materials in CO2 injection wells under supercritical conditions," Journal of Petroleum Science and Engineering, vol. 151, pp. 311-317, 2017.

17.X. Li, C. Tan and J.-C. Roegiers, "Effects of packer on hydraulic fractures initiated from highly-deviated and horizontal boreholes," International Journal of Rock Mechanics and Mining Sciences, vol. 34, no. 3-4, pp. 260.e1-260.e21, 1997

18.Atkinson, J. Desroches, D. Eftaxiopoulos and M. Thiercelin, "Wellbore stresses induced by the nonlinear deformation of an inflatable packer," Journal of Engineering Mathematics, vol. 41, pp. 305-327, 2001.

19.L. Jun, Z. Hongliang, L. Xian, L. Qingyou, X. Guohua and S. Xianming, "Experimental study on the mechanical responses of downhole tools in highly-deviated waterflooding well," Journal of Petroleum Science and Engineering, vol. 171, pp. 495-506, 2018.

20.B. M. Rodrigues, A. A. Cerqueira, C. Russo and M. R. da C. Marques, "Electroflocculation applied to the treatment of oil production wastewater," Periódico Tchê Química, vol. 7, no. 14, pp. 7-15, 2010.

21.A. A. Cerqueira, M. R. da C. Marques and C. Russo, "Application of the technique of electroflocculation using alternate current in treatment of water production from oil industry," Periódico Tchê Química, vol. 7, no. 13, pp. 33-45, 2010 


\section{AUTHORS PROFILE}

Roman Alexandrovich Vaganov works in Institute

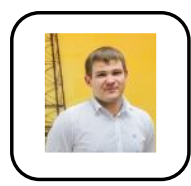
the position of the Senior Lecturer. Education: engineer with a degree in Chemical Technology of Natural Energy and Carbon Materials, Siberian Federal University, Krasnoyarsk, Russia.

Fields of scientific interests: physical modeling of hydrocarbon processing; fight against scaling on oilfield equipment; physico-chemical methods for preventing asphalt-resinous-paraffin deposits during oil production and transportation; increasing the efficiency of technology for the preparation of oil, water, associated petroleum gas; study of the stability of water-oil emulsions; modeling of hydrate-free operation of wells in conditions of high gas factor; associated petroleum gas utilization methods; processing gaseous hydrocarbons into synthetic liquid fuels.

Scientific activity: author of more than 10 scientific publications, participated in 6 international conferences. Winner of the competition of young scientists, held in the framework of the conference "Oil and Gas of Eastern Siberia-2016", the international congress and exhibition "Aluminum of Siberia-2016", the international competition of young scientists and students "Science of the future-science of young-2015" Contractor for 2 grants of the Ministry of Education and Science of Russia.

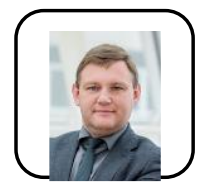

Fedor Anatolyevich Buryukin works at Institute of Oil and Gas, Siberian Federal University, Russia, at the position of the Head of the Department of Chemical Technology of Natural Energy and Carbon Materials.

Education: engineer specializing in Chemical Technology of Organic Substances, Siberian State Technological University, Russia;

Fields of scientific interests: research and development of new methods for increasing oil recovery, combating complications in oil production, oilfield chemistry, modeling of technological equipment.

Scientific activity: Head of 26 research projects in the interests of industrial enterprises in the areas of monitoring, modernization of existing technological processes and the development of new technologies for oil production and refining, the study of natural hydrocarbon raw materials. The author of 65 scientific publications, 4 certificates of registration of computer programs.

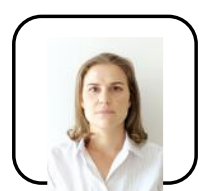

Svetlana Sergeevna Kositcyna is the Candidate of Technical Sciences. She works at Institute of Oil and Gas, Siberian Federal University, Russia, at the position of the Associate Professor.

Education: engineer specializing in Chemical Technology of Organic Substances, Siberian State Technological University, Krasnoyarsk, Russia;

Master's program in the Reliability of Technological Machines and Equipment for the Oil and Gas Complex, Siberian Federal University, Krasnoyarsk, Russia.

Fields of scientific interests: research and development of new methods for increasing oil recovery, combating complications in oil production, oilfield chemistry, modeling of technological equipment.

Scientific activity: Took part in the implementation of more than 10 scientific projects in the interests of industrial enterprises in the areas of monitoring, modernization of existing technological processes and the development of new technologies for oil production and refining, and the study of natural hydrocarbon raw materials. The author of 21 scientific publications.

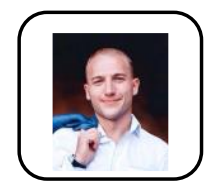

Maksim Valerievich Zhukov works at SSK Group LLC, at the position of the Director.

Education: Master of Economics, International Banking Institute, St. Petersburg, Russia

Field of activity: development, manufacture and sale of technical equipment for drilling, operation and repair of oil and gas wells, sale of oil and gas equipment.

Scientific activity: SKK Group independently and in partnership with scientific and engineering companies carries out the development and implementation of new equipment for drilling and oil production. The company has developed new designs of gas valves, anti-corrosion devices, drillable and removable packers. The company is a partner of Siberian Federal University, Russia, in the project "Development of equipment for eliminating leaks in oil and gas well production cores", implemented with financial support from the Russian Ministry of Education and Science. SKK Group carries out work on the implementation of research results, including the selection of the object of implementation, production and field testing of a trial batch of packer, development of technical documentation necessary for the subsequent organization of mass production. 